Research article

Open Access

\title{
An Improved 2-step Liquid Culture System for Efficient In Vitro Shoot Proliferation of Sundew (Drosera rotundifolia L.)
}

\section{Christoph WaWrosch *, Eva BendA, Brigitte KoPP}

Department of Pharmacognosy, University of Vienna, Althanstr. 14, A-1090, Vienna, Austria

* Corresponding author. E-mail: christoph.wawrosch@univie.ac.at (C. Wawrosch)

Sci Pharm. 2009; 77: 827-835

doi:10.3797/scipharm.0908-03

Published: $\quad$ September $21^{\text {st }} 2009$

Accepted: $\quad$ September $21^{\text {st }} 2009$

Received: $\quad$ August $4^{\text {th }} 2009$

This article is available from: http://dx.doi.org/10.3797/scipharm.0908-03

(C) Wawrosch et al; licensee Österreichische Apotheker-Verlagsgesellschaft m. b. H., Vienna, Austria.

This is an Open Access article distributed under the terms of the Creative Commons Attribution License (http://creativecommons.org/licenses/by/3.0/), which permits unrestricted use, distribution, and reproduction in any medium, provided the original work is properly cited.

\begin{abstract}
An efficient procedure for in vitro shoot production of the medicinal plant sundew (Drosera rotundifolia L.) was developed. Of three cytokinins tested, zeatin (ZEA) at a concentration of $2 \mu \mathrm{M}$ resulted in the formation of large numbers of adventitious shoots on leaf explants. A larger size of the small shoots was achieved by combining a 2-weeks preculture with ZEA (step 1: shoot induction) with a 5-weeks main culture without plant growth regulators (step 2: shoot elongation). Liquid media were superior to semisolid media: An average of 27.4 shoots per leaf explant, and 53.3 shoots per shoot explant were achieved. The 2-step culture system with liquid media permits a comparatively cheap micropropagation of sundew as well as in vitro biomass production, with potential for scale-up.
\end{abstract}

\section{Keywords}

Endangered $\bullet$ Medicinal Plant $•$ Liquid Medium $•$ Micropropagation

\section{Introduction}

The sundews (Drosera sp.) comprise about 150 species distributed all over the world and being best represented in Australia, Africa and South America. In Europe, three species can be found (D. rotundifolia L., D. intermedia Hayne and D. anglica Huds.), and especially the former has been used against affections of the respiratory organs for a long time past [1]. Recently, antispasmodic and anti-inflammatory effects have been demonstrated in vitro for $D$. rotundifolia [2]. The main active compounds are naphthoquinones and 
flavonoids; preparations containing sundew extracts are of high interest especially in pediatrics due to the absence of side-effects. Unfortunately, the European sundews have become very rare mainly due to the destruction of their habitats which typically are peats and bogs. Therefore the plants are listed as endangered or are even protected in many European countries [3]. In the past years this situation led to the supply of alternative species like e.g. D. madagascariensis DC, but the drug material is of low quality [4] and ecological problems due to over-exploitation of the natural populations are expected, too [3]. Due to the fact that presently the European Pharmacopoeia does not include a Drosera monograph, any crude sundew drug available in the market can be used for the preparation of phytomedicines. However, for homoeopathic purposes the German Homoeopathic Pharmacopoeia demands the use of fresh plant material of $D$. rotundifolia, D. intermedia or D. anglica [5].

Although propagation of sundews is possible through seeds or vegetatively through leaf cuttings [6], the conventional methods are time consuming and problematic, e.g. with species where seed germination may take several months. In vitro multiplication may overcome these restrictions because of faster growth and higher output. Last but not least the possibility of establishing high quality clones (i.e. rich in naphthoquinones and/or flavonoids) would be valuable for medicinal purposes. A number of micropropagation protocols using shoot or leaf explants have been presented mostly for $D$. rotundifolia, $D$. capensis, D. natalensis and D. hilaris [7-12]. However, these papers reveal that as a major problem the newly formed shoots were either very small in size, or they showed inhibited development on media with high regeneration rates. While there is evidence that in many plant species organized cultures produce less of the typical secondary compounds than the intact plant [13], it has been reported that the naphthoquinone content in in vitro cultivated $D$. rotundifolia can be distinctly higher than in vivo $[14,15]$. Hence, the in vitro production of naphthoquinone rich crude drug material would be an interesting option, too. Thus, as it has been stated that adventitious shoot regeneration from leaf explants readily occurs on plant growth regulator (PGR)-free medium [7, 8], it was of interest to study a) how the concentration of PGRs affects either regeneration rates and size of the regenerated shoots, and b) how to improve the procedure with the aim of high multiplication side by side with a reasonable size of the regenerated shoots. In this, we wanted to lay emphasis on the possibility of using liquid media which would allow easier handling of the cultures, scale-up and automation, and thus an overall cost reduction [16]. The scope of the present study was therefore to establish an efficient procedure for shoot proliferation aiming at in vitro biomass production as well as plant propagation.

\section{Results and Discussion}

Concentration series of $2,4,6,8$, and $10 \mu \mathrm{M}$ of the plant growth regulators (PGR) regulators kinetin (KIN), zeatin (ZEA) and $N^{6}$-benzylaminopurine (BAP) in half strength basal MS medium [17] were tested with a clone of $D$. rotundifolia. Medium free of PGR has been described to induce adventitious shoot formation in Drosera $[7,8,10,18]$. Thus, half strength basal MS medium without regulators was used as control for the experiments.

The three tested cytokinins had different effects on adventitious shoot regeneration from leaf explants of $D$. rotundifolia (table 1). First of all, an average of more than 8 shoots per explant were formed on basal medium without PGR. The average shoot diameter (ca. 
$14 \mathrm{~mm}$ ) was higher than in all other treatments. Similarly, the use of PGR free medium has e.g. also been reported by Bekesiova et al. [19] and Bobak et al. [8]. The explants were obviously very sensitive to cytokinin supplements both in terms of regeneration and shoot size. The addition of KIN resulted in comparatively low shoot regeneration which was not significantly different to the multiplication in the control cultures. Quiet high numbers of shoots were obtained with 2-8 $\mu \mathrm{M}$ ZEA while the regeneration was lower on medium with $10 \mu \mathrm{M}$ of the PGR, although again not significantly different to the treatments with 4,6 , or $8 \mu \mathrm{M}$ ZEA. Unfortunately, the shoot size decreased from just acceptable $5 \mathrm{~mm}(2 \mu \mathrm{M} \mathrm{Z})$ down to less than $3 \mathrm{~mm}(10 \mu \mathrm{M}$ ZEA). Evidently, BAP was not suitable for $D$. rotundifolia: not only the percentage of responding explants was much lower than on the other media, but also only minute buds were formed, although in large numbers. These buds covered the whole explant and it was not feasible to count them. Anyway, it would not be practicable to further process such small buds. These results obtained with BAP were in contrast to those reported e.g. by Hirsikorpi et al. [20] or Bonnet et al. [14] who used up to $4.5 \mathrm{mg} / \mathrm{L}(20 \mu \mathrm{M})$ or $10 \mu \mathrm{M}$ BAP, respectively. However, in these studies no data about the size of the regenerated shoots are presented.

Tab. 1. Influence of cytokinin type and concentration on shoot regeneration from leaf explants of Drosera rotundifolia $(n=30)$

\begin{tabular}{|c|c|c|c|c|}
\hline \multicolumn{2}{|c|}{$\begin{array}{c}\text { Growth } \\
\text { regulator }(\mu \mathrm{M})\end{array}$} & $\begin{array}{l}\text { Responding } \\
\text { explants }(\%)^{*}\end{array}$ & $\begin{array}{c}\text { Total } \\
\text { shoots }\end{array}$ & $\begin{array}{c}\text { Shoots per responding } \\
\text { explant } \pm S E^{*}\end{array}$ \\
\hline \multicolumn{2}{|c|}{0 (control) } & $100.0 \mathrm{a}$ & 257 & $8.6 \pm 0.6 \mathrm{a}$ \\
\hline \multirow[t]{5}{*}{ KIN } & 2 & $96.7 \mathrm{ab}$ & 304 & $10.1 \pm 1.3 \mathrm{a}$ \\
\hline & 4 & $86.7 \mathrm{ab}$ & 360 & $12.0 \pm 1.3 a b$ \\
\hline & 6 & $100.0 \mathrm{a}$ & 335 & $11.2 \pm 1.2 \mathrm{ab}$ \\
\hline & 8 & $76.7 \mathrm{bcd}$ & 210 & $7.0 \pm 1.2 \mathrm{a}$ \\
\hline & 10 & $80.0 \mathrm{abc}$ & 215 & $7.2 \pm 0.9 \mathrm{a}$ \\
\hline \multirow[t]{5}{*}{ ZEA } & 2 & $86.7 \mathrm{ab}$ & 705 & $23.5 \pm 2.9 d$ \\
\hline & 4 & $90.0 \mathrm{ab}$ & 620 & $20.7 \pm 2.6 \mathrm{~cd}$ \\
\hline & 6 & $80.0 \mathrm{abc}$ & 660 & $22.0 \pm 3.0 \mathrm{~cd}$ \\
\hline & 8 & $93.3 \mathrm{ab}$ & 640 & $21.3 \pm 2.6 \mathrm{~cd}$ \\
\hline & 10 & $76.7 \mathrm{bcd}$ & 510 & $17.0 \pm 2.6 \mathrm{bc}$ \\
\hline \multirow[t]{5}{*}{ BAP } & 2 & 60.0 cde & $\mathrm{nc}^{\dagger}$ & - \\
\hline & 4 & $56.7 \mathrm{de}$ & $\mathrm{nc}$ & - \\
\hline & 6 & $53.3 \mathrm{e}$ & $\mathrm{nc}$ & - \\
\hline & 8 & $46.7 \mathrm{e}$ & $\mathrm{nc}$ & - \\
\hline & 10 & $23.3 \mathrm{f}$ & $\mathrm{nc}$ & - \\
\hline
\end{tabular}

The results of the experiments presented above confirmed the well known properties of cytokinins, i.e. induction of adventitious shoot formation and inhibition of shoot elongation. As a consequence, a time-limited exposure to cytokinin-containing medium (preculture, step 1), followed by inoculation on PGR-free medium (main culture, step 2), should improve the overall results in terms of high regeneration rates combined with a larger shoot size. 
For the preculture, leaf explants were inoculated on semisolid medium 1/2MS medium supplemented with $2 \mu \mathrm{M}$ ZEA for $1,2,3$, or 4 weeks, respectively. Subsequently the explants were transferred to PGR-free half strength MS medium (1/2MS) in baby food jars for further 5 weeks. Leaf explants inoculated on 1/2MS medium without PGR for 7 weeks served as control. As summarized in table 2, for the two-step culture on semisolid media we recorded an average of 9 shoots per leaf explant in the control treatment, with a mean size of nearly $14 \mathrm{~mm}$. A preculture on medium with ZEA resulted in increasing shoot numbers, but also to reduced shoot size, making it more difficult to further handle the cultures. According to these results a 2-weeks preculture on semisolid medium with $2 \mu \mathrm{M}$ ZEA, followed by a 5-weeks inoculation on PGR-free medium, seemed to result in good multiplication rates together with feasible subculturing and handling of the cultures.

Although initially the two-step procedure led to improved shoot size, the multiplication rate was inferior to that obtained with continuous zeatin treatment. A previous study [8] pointed out that the regeneration capacity of leaf explants was increased by using liquid medium. Own preliminary studies (unpublished data) had shown that $D$. rotundifolia can be propagated in liquid medium, without any symptoms of hyperhydricity. The adoption of liquid media would also reduce labour input because of easier inoculation and exchange of media.

Subsequently we replaced the semisolid media for pre- and main culture by respective liquid ones in Erlenmeyer flasks. As shown in table 2 a preculture of 2 or 3 weeks resulted in significantly better regeneration than on semisolid media.

Tab. 2. 2-step culture: influence of variable cytokinin preculture ( $2 \mu \mathrm{M} Z \mathrm{ZEA})$ and main culture (without PGR) on shoot regeneration (mean \pm SE) from leaf explants of Drosera rotundifolia $(\mathrm{n}=30)$ using semisolid or liquid media

\begin{tabular}{|c|c|c|c|c|c|c|}
\hline \multicolumn{2}{|c|}{ Treatment (weeks) } & $\begin{array}{c}\text { Responding } \\
\text { explants } \\
(\%)^{*}\end{array}$ & $\begin{array}{c}\text { Total } \\
\text { shoots }\end{array}$ & $\begin{array}{c}\text { Shoots per } \\
\text { explant }^{*}\end{array}$ & $\begin{array}{l}\text { Shoot } \\
\text { length } \\
(\mathrm{mm})^{*}\end{array}$ & 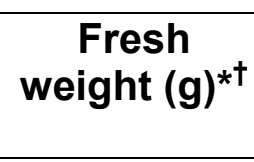 \\
\hline \multicolumn{7}{|c|}{ preculture main culture } \\
\hline \multicolumn{7}{|c|}{ semisolid } \\
\hline 0 & 7 & $100.0 \mathrm{a}$ & 270 & $9.0 \pm 0.9 \mathrm{a}$ & $13.8 \pm 0.5 \mathrm{a}$ & $0.58 \pm 0.1 \mathrm{a}$ \\
\hline 1 & 5 & $100.0 \mathrm{a}$ & 326 & $10.9 \pm 1.0 a$ & $12.9 \pm 0.6 \mathrm{ab}$ & $0.75 \pm 0.1 \mathrm{ab}$ \\
\hline 2 & 5 & $100.0 \mathrm{a}$ & 424 & $14.1 \pm 0.7 \mathrm{ab}$ & $11.5 \pm 0.5 b$ & $0.99 \pm 0.1 \mathrm{ab}$ \\
\hline 3 & 5 & $96.7 \mathrm{a}$ & 539 & $18.0 \pm 1.5 \mathrm{bc}$ & $7.6 \pm 0.4 \mathrm{c}$ & $0.57 \pm 0.1 \mathrm{a}$ \\
\hline \multicolumn{7}{|c|}{ (10) } \\
\hline 0 & 7 & $100.0 \mathrm{a}$ & 280 & $9.3 \pm 0.7 \mathrm{a}$ & $17.1 \pm 0.4 d$ & $0.92 \pm 0.1 \mathrm{ab}$ \\
\hline 1 & 5 & $100.0 \mathrm{a}$ & 444 & $14.8 \pm 1.6 \mathrm{abc}$ & $14.2 \pm 0.5 a$ & $1.26 \pm 0.1 \mathrm{~b}$ \\
\hline 2 & 5 & $100.0 \mathrm{a}$ & 823 & $27.4 \pm 2.5 \mathrm{~d}$ & $12.8 \pm 0.5 a b$ & $2.00 \pm 0.2 c$ \\
\hline 3 & 5 & $80.0 \mathrm{~b}$ & 848 & $28.3 \pm 3.2 \mathrm{~d}$ & $5.0 \pm 0.3 e$ & $0.74 \pm 0.1 \mathrm{ab}$ \\
\hline 4 & 5 & $66.7 \mathrm{c}$ & 621 & $20.7 \pm 3.5 c$ & $7.9 \pm 0.8 \mathrm{c}$ & $1.19 \pm 0.4 b$ \\
\hline
\end{tabular}


However, the 3-weeks cytokinin treatment led to reduced shoot size, and the percentage of responding explants decreased, too. Thus, and because the highest biomass yield per culture vessel could be achieved, a preculture of 2 weeks can be recommended. While the positive influence of liquid medium on shoot regeneration was similar to the findings of Bobák et al. [8], these authors obtained an average number of 18.3 shoots per explant in medium without PGR. In our 2-step procedure we could achieve an average number of 27.4 shoots, which corresponds to a 50 percent increase. The successful application of 2-step culture systems has previously been described for a number of different plants, like e.g. Swertia chirata [21], Charybdis numidica [22], Curcuma longa [23], or Anacardium occidentale [24].

Beside leaf explants, whole shoot rosettes have also been used for the in vitro multiplication of $D$. rotundifolia and other sundew species [11, 25-27]. As compared to leaf explants, multiplication from whole rosettes is certainly less labour-intensive (preparation of explants, inoculation) although a lower total number of propagules per donor shoot has to be accepted. Nevertheless, we applied the 2-step culture system to shoot explants, again also comparing semisolid with liquid media. An average of about 28 shoots per explant were obtained on semisolid media (table 3). By using liquid media this value could be nearly doubled, while under both culture regimes an average rosette diameter of ca. 11 $\mathrm{mm}$ was achieved. A clear advantage of the liquid media is the much easier inoculation: While with semisolid media each shoot has to be systematically placed on the medium surface, with the liquid system the explants are just easily dropped into the flask. Regenerated shoots were easily rooted in liquid 1/2MS medium without growth regulators, and acclimatisation was feasible without losses.

Tab. 3. Multiplication of Drosera rotundifolia shoot explants in the 2-step culture system (preculture: $2 \mu \mathrm{M}$ ZEA; main culture: no PGR) using semisolid or liquid media $(n=30)$

\begin{tabular}{cccc}
\hline $\begin{array}{c}\text { Treatment } \\
\text { preculture } \\
(2 \text { weeks }) \quad \text { main culture } \\
(5 \text { weeks })\end{array}$ & Shoots / explant * & $\begin{array}{c}\text { Shoot length } \\
(\mathrm{mm})^{*}\end{array}$ & $\begin{array}{c}\text { Fresh weight } \\
(\mathrm{g})^{*}\end{array}$ \\
\hline semisolid & $28.2 \pm 1.2 \mathrm{a}$ & $11.6 \pm 0.3 \mathrm{a}$ & $2.74 \pm 0.1 \mathrm{a}$ \\
liquid & $53.3 \pm 1.4 \mathrm{~b}$ & $11.2 \pm 0.1 \mathrm{a}$ & $4.77 \pm 0.3 \mathrm{~b}$ \\
\hline
\end{tabular}

* Within one column, mean values followed by the same letters are not significantly different at the $5 \%$ level (Student's T-test); ${ }^{\dagger}$ Biomass per culture vessel, average of 6 vessels; average inoculum per vessel: $0.182 \mathrm{~g}$

With the 2-step liquid culture system for Drosera rotundifolia high multiplication rates can be achieved with both leaf or shoot explants. Concomitantly, too small sized shoots, which result from continuous cytokinin action, are avoided due to the main culture without PGR. Even better propagation can be achieved through the use of liquid media. The latter step has the additional advantage of reduced costs of the nutrient media themselves, simplier and quicker inoculation process, and potential for scale-up to bioreactor dimensions. This could finally be applied for both micropropagation purposes and the direct production of shoot biomass of Drosera rotundifolia for further processing and preparation of herbal medicinal products. 


\section{Experimental}

\section{Plant material}

The axenic sundew clone used in the present study was established from seeds as described previously [11] and maintained on modified basal MS medium [17] with halfstrength macronutrients, $1 \%$ sucrose and 0.8\% agar (MERCK 1614). The cultures were transferred to fresh medium every 12 weeks. For the induction of adventitious shoots whole leaves or shoot rosettes (diameter 15-20 mm) were used as explants.

\section{Shoot induction and proliferation}

Modified basal MS medium with a half-strength of macronutrient concentrations and $1 \%$ sucrose (household quality) was used throughout the experiments (1/2 MS medium). Semisolid media were solidified with $0.8 \%$ agar. The plant growth regulators (PGRs) used were $\mathrm{N}^{6}$-benzylaminopurine (BAP; FLUKA 13153), kinetin (KIN; SIGMA K-0753), and zeatin (ZEA; SIGMA Z-0876). All media were adjusted to $\mathrm{pH} 5.7 \pm 0.1$ with $\mathrm{KOH}$ or $\mathrm{HCl}$ before autoclaving at $121^{\circ} \mathrm{C}$ for $20 \mathrm{~min}$. Disposable petri dishes (60 x $15 \mathrm{~mm}$, with vents) were used for evaluating the effects of cytokinin type and concentration on leaf explants (size $0.5 \mathrm{~cm}$ ). In the main experiment, baby food jars (55 mm diameter, $55 \mathrm{~mm}$ height; 40 $\mathrm{ml}$ medium) with MAGENTA B-Caps ${ }^{\circledR}$, and Erlenmeyer flasks (250 ml; $50 \mathrm{ml}$ medium) with cellulose plugs were used. Five explants (leaf explants: size $0.5 \mathrm{~cm}$; shoot explants: $15-20$ $\mathrm{mm})$ per culture vessel and 6 replicates were inoculated for each treatment. Erlenmeyer flasks with liquid media were kept on a rotary shaker at $80 \mathrm{rpm}$. All cultures were incubated at $25 \pm 1^{\circ} \mathrm{C}$ and a $16 \mathrm{~h}$ photoperiod of $50 \mu \mathrm{M} \mathrm{m}^{-2} \mathrm{~s}^{-1}$ (SYLVANIA Gro-Lux ${ }^{\circledR}$ fluorescent tubes).

\section{Rooting and acclimatisation}

In vitro proliferated shoots (ca. $1.5-2 \mathrm{~cm}$ in size) were excised from the initial explants and inoculated in liquid 1/2MS medium without growth regulators. After 2 weeks the plantlets were washed with water and transferred to sphagnum peat ("HANSA ${ }^{\circledR}$ Torf", FLORAGARD) soaked with a $0.1 \%$ aqueous solution of the fungicide Previcur ${ }^{\circledR} \mathrm{N}$ (AGREVO, $750 \mathrm{~g} \mathrm{~L}^{-1}$ propamocarb hydrochloride). Acclimatisation took place in a mist chamber with in initial relative humidity of $90 \%$, which was gradually lowered to $60 \%$ during a period of 2 weeks.

\section{Evaluation and interpretation}

The number of regenerated shoots, shoot sizes, and biomass per vessel were recorded at the end of the treatment, and experiments were performed twice. The corresponding average values as well as standard errors (SE) and significance tests were calculated with the software package Statistica for Windows, version 6.1 (STATSOFT, Inc.).

\section{Acknowledgement}

The authors are grateful to Christina Ruzsits for her assistance in the experimental work. 


\section{Authors' Statement}

\section{Competing Interests}

The authors declare no conflict of interest.

\section{References}

[1] Krenn L, Kartnig T.

Sonnentau - Aktuelles über medizinisch genutzte Drosera-Arten.

Z Phytother. 2005; 26: 197-202.

doi:10.1055/s-2005-915657

[2] Krenn L, Beyer G, Pertz HH, Karall E, Kremser M, Galambosi B, Melzig MF. In vitro antispasmodic and anti-inflammatory effects of Drosera rotundifolia. Arzneimittelforschung. 2004; 54, 402-405.

PMid:15344845

[3] Lange D.

Europe's medicinal and aromatic plants: their use, trade and conservation.

Cambridge: TRAFFIC International, 1998.

[4] Krenn L, Länger R, Kopp B.

Qualitätsprüfung von Sonnentaukraut. 2. Botanische Identitätsprüfung sowie qualitative und quantitative Naphthochinon-Bestimmung an Handelsmustern.

Dtsch Apoth Z. 1995; 135: 867-870.

[5] Drosera.

Homöopathisches Arzneibuch 2008, Volume 1.

Stuttgart: Deutscher Apotheker Verlag, 2008.

[6] Lecoufle M.

Carnivorous plants.

London: Blandford Press, 1990.

[7] Anthony JL.

In Vitro Propagation of Drosera spp.

HortScience. 1992; 27: 850.

[8] Bobák M, Blehová A, Krištín J, Oveck AM, Šamaj J.

Direct plant regeneration from leaf explants of Drosera rotundifolia cultured in vitro.

Plant Cell Tissue Org Cult. 1995; 43: 43-49.

doi:10.1007/BF00042670

[9] Crouch IJ, Finnie JF, Van Staden J.

Studies on the isolation of plumbagin from in vitro and in vivo grown Drosera species.

Plant Cell Tissue Org. Cult. 1990; 21: 79-82.

doi:10.1007/BF00034496

[10] Kukulczanka K.

Micropropagation and in vitro germplasm storage of Droseraceae.

Bot Gard Microprop News. 1991; 1: 38-42.

[11] Wawrosch C, Markotai J, Steinberger B, Kopp B.

In vitro-Vermehrung von Sonnentau-Arten.

Sci Pharm. 1996; 64: 709-717.

[12] Jang G-W, Park R-D.

Mass propagation of Sundew, Drosera rotundifolia L. through shoot culture.

J Plant Biotechnol. 1999; 1: 97-100. 
[13] Charlwood BV, Charlwood KA, Molina-Torres J.

Accumulation of secondary compounds by organized plant cultures.

In: Charlwood BV, Rhodes MJC, editors.

Secondary Products from Plant Tissue Culture.

New York: Oxford University Press, 1990: 167-200.

[14] Bonnet M, Coumans M, Ramaut JL, Gaspar T.

Vegetative multiplication in vitro of the sundew Drosera rotundifolia.

Arch Int Physiol Biochim. 1984; 92: 16-17.

[15] Kämäräinen T, Laine K, Hohtola A, Jalonen J.

Production of 7-methyljuglone in Drosera rotundifolia in vitro and ex vitro.

Acta Hort. 2003; 616: 507-510.

[16] Aitken-Christie J.

Automation.

In: Debergh PC, Zimmermann RH, editors.

Micropropagation: technology and application.

Dordrecht: Kluwer Academic Publishers, 1991: 363-388.

[17] Murashige T, Skoog F.

A revised medium for rapid growth and bioassays with tobacco tissue culture.

Physiol Plant. 1962; 15: 473-497.

doi:10.1111/j.1399-3054.1962.tb08052.x

[18] Van Waes J.

Multiplication of sundew (Drosera) in test tubes.

Verbondsnieuws Belgische Sierteelt 1985; 26: 547-551.

[19] Bekesiova I, Nap J-P, Mlynarova L.

Isolation of high quality DNA and RNA from leaves of the carnivorous plant Drosera rotundifolia.

Plant Mol Biol Rep. 1999; 17: 269-277.

doi:10.1023/A:1007627509824

[20] Hirsikorpi M, Kämäräinen T, Teeri T, Hohtola A.

Agrobacterium-mediated transformation of round leaved sundew (Drosera rotundifolia L.).

Plant Sci. 2002; 162: 537-542.

doi:10.1016/S0168-9452(01)00592-1

[21] Wawrosch C, Maskay N, Kopp, B.

Micropropagation of the threatened Nepalese medicinal plant Swertia chirata Buch.-Ham. Ex Wall.

Plant Cell Rep. 1999; 18: 997-1001.

doi:10.1007/s002990050697

[22] Kongbangkerd A, Wawrosch C.

Improved shoot regeneration from nodules of Charybdis numidica in a temporary immersion system. J Hort Sci Biotechnol. 2003; 78: 650-655.

[23] Prathanturarug S, Soonthornchareonnon N, Chuakul W, Phaidee Y, Saralamp P.

Rapid micropropagation of Curcuma longa using bud explants pre-cultured in thidiazuronsupplemented liquid medium.

Plant Cell Tissue Org Cult. 2005; 80: 347-351.

doi:10.1007/s11240-004-1020-x

[24] Aliyu OM.

Application of tissue culture to cashew (Anacardium occidentale L.) breeding: An appraisal.

Afr J Biotechnol. 2005; 4: 1485-1489.

[25] Reichling J, Sauerwein M, Wink M.

Naphthoquinone production in in-vitro-cultures of Drosera communis ST.HIL.

Drogenrep. 1995; 8: 26-27. 
[26] Budzianowski J.

Naphthohydroquinone glucosides of Drosera rotundifolia and $D$. intermedia from in vitro cultures.

Phytochemistry 1996; 42: 1145-1147.

doi:10.1016/0031-9422(96)00076-3

[27] Hook I.

Naphthoquinone contents of in vitro cultured plants and cell suspensions of Dionaea muscipula and Drosera species.

Plant Cell Tissue Org Cult. 2001; 67: 281-285.

doi:10.1023/A:1012708819212 